\title{
Maritalea myrionectae gen. nov., sp. nov., isolated from a culture of the marine ciliate Myrionecta rubra
}

Correspondence

Byung C. Cho

bccho@snu.ac.kr

\section{Chung Y. Hwang, ${ }^{1}$ Kyung D. Cho, ${ }^{1}$ Wonho Yih $^{2}$ and Byung C. Cho ${ }^{1}$}

\author{
${ }^{1}$ School of Earth and Environmental Sciences and Research Institute of Oceanography, Seoul \\ National University, San 56-1, Shillim-dong, Kwanak-gu, Seoul 151-742, Republic of Korea \\ ${ }^{2}$ Department of Oceanography, Kunsan National University, San 68, Miryong-dong, Gunsan \\ 573-701, Republic of Korea
}

At the time of writing the family Hyphomicrobiaceae comprised 15 genera (List of Prokaryotic Names with Standing in Nomenclature; http://www.bacterio.cict.fr). The family is diverse in morphology, and many members of the family are budding and appendaged bacteria (i.e. the genera Ancalomicrobium, Blastochloris, Dichotomicrobium, Filomicrobium, Hyphomicrobium, Pedomicrobium, Prosthecomicrobium, Rhodomicrobium and Rhodoplanes; Garrity et al., 2005). Most species in the family have been isolated from various non-marine habitats, comprising soil, freshwater, groundwater, swamps, rhizosphere of plants, nitrifying inocula, chickens and sewage (Garrity et al., 2005). Only a few members of the family Hyphomicrobiaceae have been isolated from marine environments (e.g. Dichotomicrobium thermohalophilum, Filomicrobium fusiforme and Hyphomicrobium aestuarii; Garrity et al., 2005). Recently, a

Abbreviations: APL, aminophospholipid; DPG, diphosphatidylglycerol; GL, glycolipid; L, lipid; PC, phosphatidylcholine; PE, phosphatidylethanolamine; PG, phosphatidylglycerol; $\mathrm{PHB}$, poly- $\beta$-hydroxybutyrate; $\mathrm{PL}$, phospholipid.

The GenBank/EMBL/DDBJ accession number for the 16S rRNA gene sequence of strain CL-SK30 ${ }^{\top}$ is EF988631.

A transmission electron micrograph of a negatively stained cell of strain $\mathrm{CL}-\mathrm{SK} 3 \mathrm{O}^{\top}$ and two-dimensional thin-layer chromatograms of the polar lipids of strain $\mathrm{CL}-\mathrm{SK} 30^{\top}$ and Cucumibacter marinus $\mathrm{CL}-\mathrm{GR} 60^{\top}$ are available as supplementary material with the online version of this paper. short prosthecae bacterium affiliated to a new genus, Cucumibacter, was isolated from coastal seawater (Hwang \& Cho, 2008). In this study, a rod-shaped bacterium with peritrichous flagella was isolated from a culture of the marine ciliate Myrionecta rubra and subjected to a polyphasic taxonomic analysis.

A clonal culture of the marine phototrophic ciliate Myrionecta rubra MR-MAL01 was established and maintained as described by Yih et al. (2004). An aliquot (100 $\mu \mathrm{l})$ of the ciliate culture in the exponential phase was taken and spread on a marine agar 2216 (MA; Difco) plate, and incubated at $20{ }^{\circ} \mathrm{C}$ for 1 week. Strain CL-SK30 ${ }^{\mathrm{T}}$ was isolated and was subsequently streaked onto fresh MA at $20{ }^{\circ} \mathrm{C}$. The purification procedure was repeated four times. Growth of strain CL-SK30 $0^{\mathrm{T}}$ occurred faster at $30{ }^{\circ} \mathrm{C}$ than at $20{ }^{\circ} \mathrm{C}$. The strain was maintained on both MA at $30{ }^{\circ} \mathrm{C}$ and in marine broth 2216 (MB; Difco) supplemented with $30 \%$ (v/v) glycerol at $-80{ }^{\circ} \mathrm{C}$.

For 16S rRNA gene amplification by PCR, DNA was extracted from a single colony by using a boiling method (Englen \& Kelley, 2000). The crude extracts served as a DNA template for the PCRs, which included Taq DNA polymerase (Bioneer) and primers 27F and 1492R (Lane, 1991). The PCR product was purified by using an AccuPrep PCR purification kit (Bioneer) and the direct sequence of the purified 16S rRNA gene was determined 
using an Applied Biosystems automated sequencer (ABI3730XL) at Macrogen, Seoul, Korea. An almostcomplete 16S rRNA gene sequence of strain CL-SK30 ${ }^{\mathrm{T}}$ (1352 nucleotides) was obtained and was compared with $16 \mathrm{~S}$ rRNA gene sequences available in GenBank using BLASTN searches (Altschul et al., 1990). The sequence of strain CL-SK30 ${ }^{\mathrm{T}}$ was aligned manually with those of species of the family Hyphomicrobiaceae, obtained from GenBank and Ribosomal Database Project II (Cole et al., 2007) databases, using known 16S rRNA secondary-structure information. Phylogenetic trees were obtained by using the neighbour-joining (Saitou \& Nei, 1987), maximumparsimony (Fitch, 1971) and maximum-likelihood (Felsenstein, 1981) methods. An evolutionary distance matrix for the neighbour-joining method was generated according to the model of Jukes \& Cantor (1969). The robustness of the tree topologies was assessed by bootstrap analyses based on 1000 replications for the neighbourjoining and maximum-parsimony methods and 100 replications for the maximum-likelihood method. Alignment analysis was carried out using the jPHYDIT program (Jeon et al., 2005), and phylogenetic analyses were performed using MEGA 4 (Tamura et al., 2007) and PAUP 4.0 (Swofford, 1998). Likelihood parameters were estimated by using the hierarchical ratio tests in MODELTEST version 3.04 (Posada \& Crandall, 1998).

Morphological and physiological tests were performed as follows. Cucumibacter marinus CL-GR60 ${ }^{\mathrm{T}}$ was used as a reference strain for all tests. Unless otherwise specified, all phenotypic characteristics of strains CL-SK $30^{\mathrm{T}}$ and $C$. marinus $\mathrm{CL}-\mathrm{GR} 60^{\mathrm{T}}$ were based on cultures grown on MA or in $\mathrm{MB}$ at $30^{\circ} \mathrm{C}$. Gram-staining was performed as described by Smibert \& Krieg (1994). Motility of the cells was observed by using the hanging drop method (Suzuki et al., 2001). Cell morphology, bud formation and the presence and type of flagellum were observed using transmission electron microscopy (EX2; JEOL). Anaerobic growth was determined on MA and ZOF medium (Lemos et al., 1985) supplemented with agar (1.5\%), using the GasPak anaerobic system (BBL) at $30{ }^{\circ} \mathrm{C}$ for 2 weeks. Poly- $\beta$-hydroxybutyrate (PHB) granules were observed by using epifluorescence microscopy (BX60; Olympus) after Nile blue A staining (Ostle \& Holt, 1982). Bacteriochlorophyll $a$ production was determined in $90 \%$ acetone extracts using a spectrophotometer (Ultraspec 2000; Pharmacia Biotech) for cells that had been grown in MB or a defined medium (Biebl et al., 2005), either in the light or in the dark for 7 days. The presence of photosynthetic reaction centre genes, pufL and pufM, was determined by using PCR amplification with specific primers (Allgaier et al., 2003) for strains CL-SK30 ${ }^{\mathrm{T}}$ and C. marinus CL-GR60 ${ }^{\mathrm{T}}$; Porphyrobacter donghaensis SW$132^{\mathrm{T}}$ (=KCTC $12229^{\mathrm{T}}$; Yoon et al., 2004) and Escherichia coli KACC 11930 served as a positive and a negative control, respectively. PCR product using the specific primers for $p u f L$ and $p u f M$ genes was not detected for strains CL-SK30 ${ }^{\mathrm{T}}, C$. marinus CL-GR60 ${ }^{\mathrm{T}}$ or E. coli KACC 11930, but was detected for $P$. donghaensis SW-132 ${ }^{\mathrm{T}}$ (data not shown).
The temperature range for growth was examined on the basis of colony formation on MA incubated at temperatures ranging from 5 to $40{ }^{\circ} \mathrm{C}$, in increments of $5{ }^{\circ} \mathrm{C}$. The $\mathrm{pH}$ range $(\mathrm{pH} 4.2-11.8 ; \mathrm{pH} 4.2,5.4,6.3,7.2,8.0,8.8,9.8$, 10.2 and 11.8) for growth was determined by assessing changes in $\mathrm{OD}_{600}$ over the incubation period (up to 7 days) in $\mathrm{MB}$ at $30{ }^{\circ} \mathrm{C}$. Prior to autoclaving, the $\mathrm{pH}(4-12$, in increments of $1 \mathrm{pH}$ unit) was adjusted using $1 \mathrm{M} \mathrm{NaOH}$ and $1 \mathrm{M} \mathrm{HCl}$ solutions. After autoclaving and cooling, the $\mathrm{pH}$ values were measured for the subsamples of each medium, before the inoculation of cells. The tolerance of strain CL-SK30 ${ }^{\mathrm{T}}$ to sea salts (Sigma) was determined by assessing changes in $\mathrm{OD}_{600}$ in synthetic ZoBell broth $\left(1^{-1}\right.$ distilled water: Bacto peptone, $5 \mathrm{~g}$; yeast extract, $1 \mathrm{~g}$; ferric citrate, $0.1 \mathrm{~g})$ with concentrations $(0-10 \%$ in increments of $1 \%$, and $15 \%$, w/v) of sea salts at $30{ }^{\circ} \mathrm{C}$.

Oxidase and catalase tests were performed according to the protocols described by Smibert \& Krieg (1994). Hydrolysis of gelatin, starch and Tween 80 was determined according to Hansen \& Sørheim (1991). In addition, other enzyme activities were assayed using the API ZYM kit (bioMérieux) according to the manufacturer's instructions, except that the cell suspension was prepared using artificial seawater (ASW; $1^{-1}$ distilled water: $\mathrm{NaCl}, 24 \mathrm{~g} ; \mathrm{MgCl}_{2} \cdot 6 \mathrm{H}_{2} \mathrm{O}$, $10.9 \mathrm{~g} ; \mathrm{Na}_{2} \mathrm{SO}_{4}, 4 \mathrm{~g} ; \mathrm{CaCl}_{2} .2 \mathrm{H}_{2} \mathrm{O}, 1.5 \mathrm{~g} ; \mathrm{KCl}, 0.7 \mathrm{~g}$; $\mathrm{NaHCO}_{3}, 0.2$ g; KBr, 0.1 g; $\mathrm{H}_{3} \mathrm{BO}_{3}, 0.027$ g; $\mathrm{SrCl}_{2} .6 \mathrm{H}_{2} \mathrm{O}$, $0.03 \mathrm{~g}$; NaF, $0.003 \mathrm{~g}$; Lyman \& Fleming, 1940). Carbon utilization was tested on basal agar medium $[$ Tris $/ \mathrm{HCl}$, $50 \mathrm{mM}, \quad$ pH 7.5; $\quad \mathrm{NH}_{4} \mathrm{Cl}, \quad 19 \mathrm{mM} ; \quad \mathrm{K}_{2} \mathrm{HPO}_{4} \cdot 3 \mathrm{H}_{2} \mathrm{O}$, $0.33 \mathrm{mM} ; \mathrm{FeSO}_{4} .7 \mathrm{H}_{2} \mathrm{O}, 0.1 \mathrm{mM} ; 1.5 \%$ Bacto agar (Difco) in ASW ( $\mathrm{NaCl}, 400 \mathrm{mM} ; \mathrm{MgSO}_{4} .7 \mathrm{H}_{2} \mathrm{O}, 100 \mathrm{mM}$; $\left.\mathrm{KCl}, 20 \mathrm{mM} ; \mathrm{CaCl}_{2} \cdot 2 \mathrm{H}_{2} \mathrm{O}, 20 \mathrm{mM}\right)$ ] containing $0.2 \%$ of the carbon source as described by Baumann \& Baumann (1981), but with a slight modification that full-strength ASW instead of half-strength ASW was used. Strain CLSK $30^{\mathrm{T}}$ was incubated for 2 weeks at $30{ }^{\circ} \mathrm{C}$ and carbon utilization was scored as negative when growth was equal to or less than that in the negative control with no carbon source. Resistance to antibiotics was determined by using the disc-diffusion plate method (Bauer et al., 1966).

Polar lipids were extracted using the procedures described by Minnikin et al. (1984) and identified by using twodimensional TLC followed by spraying with the appropriate detection reagents (Komagata \& Suzuki, 1987). The fatty acid methyl esters of whole cells of strain CL-SK30 ${ }^{\mathrm{T}}$ grown on tryptic soy agar (TSA; Difco), supplemented with $2.5 \%(\mathrm{w} / \mathrm{v}) \mathrm{NaCl}$, at $25{ }^{\circ} \mathrm{C}$ for 7 days were analysed using gas chromatography, according to the instructions of the Microbial Identification System (MIDI) at the Korean Culture Center of Micro-organisms (KCCM) in Seoul, Korea. The quinone system was determined according to Minnikin et al. (1984) and analysed by using HPLC as described by Collins (1985). The DNA G $+\mathrm{C}$ content was analysed using HPLC (HP 100; Hewlett Packard) analysis of deoxyribonucleosides as described by Mesbah et al. (1989), after DNA extraction using the method of Marmur (1961). Lambda phage DNA was used as a standard. 
Table 1. Selected characteristics that differentiate strain $\mathrm{CL}-\mathrm{SK} 30^{\top}$ (Maritalea myrionectae gen. nov., sp. nov.) from related genera in the family Hyphomicrobiaceae

Taxa: 1, strain CL-SK30 ${ }^{\mathrm{T}}$ (data from this study); 2, C. marinus CL-GR60 (Hwang \& Cho, 2008); 3, Devosia (for type strains: Nakagawa et al., 1996; Rivas et al., 2003; Yoo et al., 2006; Lee, 2007; Yoon et al., 2007; Ryu et al., 2008). +, Positive; -, negative; v, variable; Q, ubiquinone.

\begin{tabular}{|c|c|c|c|}
\hline Characteristic & $1^{*}$ & $2^{\star}$ & $3 \dagger$ \\
\hline Source of isolation & $\begin{array}{c}\text { Culture of a marine ciliate, } \\
\text { Myrionecta rubra }\end{array}$ & Seawater & $\begin{array}{r}\text { Soil, rhizosphere, nitrifying } \\
\text { inoculum, beach sediment }\end{array}$ \\
\hline Motility & + & + & $\mathrm{V}$ \\
\hline Hydrolysis of gelatin & + & + & - \\
\hline \multicolumn{4}{|l|}{ API ZYM test } \\
\hline Acid phosphatase & - & + & $\mathrm{V}$ \\
\hline$\alpha$-Chymotrypsin & + & - & - \\
\hline Cystine arylamidase & + & - & - \\
\hline$\alpha$-Glucosidase & + & - & $\mathrm{V}$ \\
\hline Lipase (C14) & - & + & - \\
\hline Trypsin & + & - & $\mathrm{V}$ \\
\hline Valine arylamidase & + & - & $\mathrm{v}$ \\
\hline Major quinone & Q-10 & Q-10 & Q-10, Q-11 \\
\hline DNA G $+C$ content $(\mathrm{mol} \%)$ & 52.7 & 62.9 & $59.1-66.2$ \\
\hline
\end{tabular}

${ }^{\star}$ Phenotypic tests were based on cultures grown on $\mathrm{MA}$ or in $\mathrm{MB}$ at $30{ }^{\circ} \mathrm{C}$.

$\dagger$ Phenotypic tests were based on cultures grown on TSA, R2A, LB, PY or YED media, supplemented with either no $\mathrm{NaCl}$ or $0.5 \% \mathrm{NaCl}$ at $25-35{ }^{\circ} \mathrm{C}$ except for Devosia subaequoris (grown on MA at $30{ }^{\circ} \mathrm{C}$; Lee, 2007).

Cells of strain CL-SK30 ${ }^{\mathrm{T}}$ were Gram-negative, rod-shaped and approximately $0.4-0.5 \mu \mathrm{m}$ wide and $1.0-2.0 \mu \mathrm{m}$ long. Cells were motile by means of peritrichous flagella (see Supplementary Fig. S1, available in IJSEM Online). Strain CL-SK $30^{\mathrm{T}}$ was strictly aerobic. PHB and bacteriochlorophyll $a$ were not present in strain CL-SK30 ${ }^{\mathrm{T}}$ or C. marinus CL$\mathrm{GR} 60^{\mathrm{T}}$. Other phenotypic characteristics of strain CL-SK $30^{\mathrm{T}}$ are given in the genus and species descriptions, and in Table 1 and Supplementary Fig. S2 (available in IJSEM Online).

The major polar lipids were phosphatidylglycerol (PG), diphosphatidylglycerol (DPG), two unidentified glycolipids (GL1 and GL2), an unidentified phospholipid (PL1) and an unidentified lipid (L; Supplementary Fig. S2, in IJSEM Online). Phosphatidylethanolamine (PE) and an unidentified aminophospholipid (APL) were detected only in minor amounts (Supplementary Fig. S2). The polar lipids PG, DPG, GL1, GL2, PL1, PE and APL were commonly detected in strain CL-SK $30^{\mathrm{T}}$ and C. marinus CL-GR60 ${ }^{\mathrm{T}}$ (Supplementary Fig. S2). The dominant fatty acid for strain CL-SK30 ${ }^{\mathrm{T}}$ was $\mathrm{C}_{18: 1} \omega 7 c(82.7 \%)$, which is a feature of the vast majority of species within the Alphaproteobacteria (Martens et al., 2006), followed by 11-methyl $\mathrm{C}_{18: 1} \omega 7 \mathrm{c}$ $(5.0 \%), \mathrm{C}_{18: 0}(3.5 \%), \mathrm{C}_{16: 0}(3.0 \%), \mathrm{C}_{10: 0}(2.4 \%)$ and $\mathrm{C}_{16: 1} \omega 7 c$ and/or $\mathrm{C}_{15: 0}$ iso $2-\mathrm{OH}(1.1 \%)$. The fatty acids $\mathrm{C}_{17: 0}$, iso- $\mathrm{C}_{19: 0}, \mathrm{C}_{17: 1} \omega 8 c$, unknown fatty acid [equivalent chain-length (ECL) 18.814) and $\mathrm{C}_{19: 1} \omega 6 \mathrm{c}$ and/or $\mathrm{C}_{17: 0}$ cyclo and/or unknown fatty acid (ECL 18.846) were present in trace amounts $(<1 \%)$. The major isoprenoid quinone was ubiquinone $10(\mathrm{Q}-10)$. The DNA G $+\mathrm{C}$ content was $52.7 \mathrm{~mol} \%$.
Analysis of the 16S rRNA gene sequence revealed a clear affiliation with the family Hyphomicrobiaceae (Fig. 1). In all the phylogenetic trees, strain CL-SK30 ${ }^{\mathrm{T}}$ formed a robust clade together with $C$. marinus, but the sequence divergence value of $8 \%$ between them indicated that the novel bacterium represented a distinct lineage. The clade containing strain CL-SK30 ${ }^{\mathrm{T}}$ and the genus Cucumibacter was clearly separated from the nearest clade containing the genera Devosia and 'Candidatus Devosia euplotis', supported by high bootstrap values (100, 98 and $85 \%$ in the neighbour-joining, maximum-parsimony and maximumlikelihood trees, respectively). The sequence similarity between strain CL-SK30 ${ }^{\mathrm{T}}$ and $C$. marinus CL-GR60 ${ }^{\mathrm{T}}$ was $92.0 \%$; sequence similarities between strain CL-SK30 ${ }^{\mathrm{T}}$ and members of the genera Devosia, Hyphomicrobium and Rhodomicrobium in the family Hyphomicrobiaceae were $89.8-91.3,86.1-88.4$ and $88.3 \%$, respectively. The low levels of sequence similarity with other bacteria and the distinct phylogenetic position indicated that strain CL$\mathrm{SK} 30^{\mathrm{T}}$ should be assigned as representing a novel genus and species.

In addition, strain CL-SK30 $30^{\mathrm{T}}$ could be differentiated from the phylogenetically closest genus Cucumibacter based on chemotaxonomic and phenotypic characteristics. The difference in $\mathrm{G}+\mathrm{C}$ contents between strain CL-SK30 and C. marinus was $>10 \mathrm{~mol} \%$ (Table 1 ), showing a distinct genetic difference at the genus level (Stackebrandt \& Liesack, 1993; Goodfellow et al., 1997). A major unidentified polar lipid in strain CL-SK30 ${ }^{\mathrm{T}}$ (i.e. L; Supplementary Fig. S2, in IJSEM Online) apparently had 


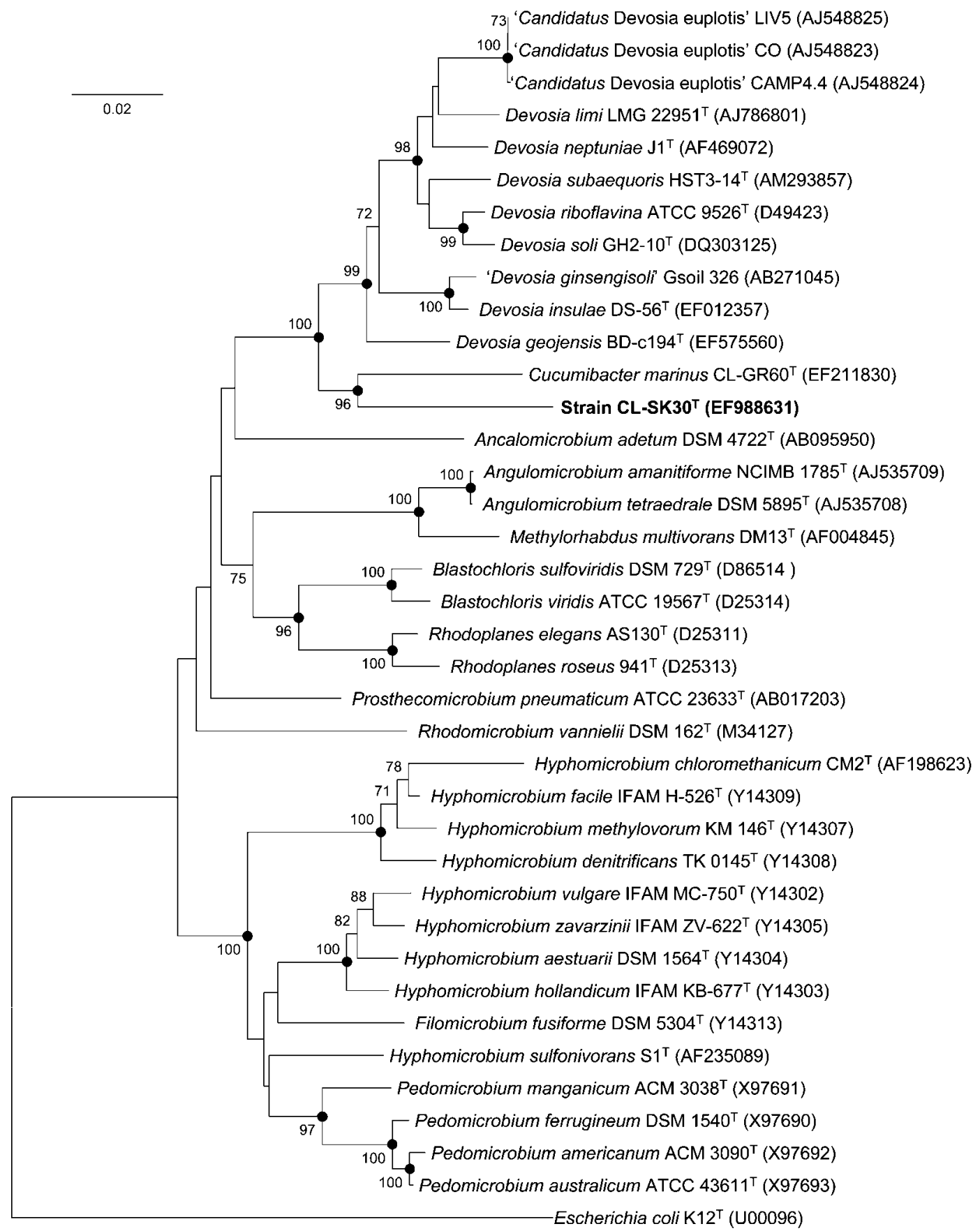

Fig. 1. Neighbour-joining tree derived from $16 \mathrm{~S}$ rRNA gene sequences for strain $\mathrm{CL}-\mathrm{SK} 30^{\top}$ and related members of the family Hyphomicrobiaceae with Escherichia coli as an outgroup. Only bootstrap values greater than $70 \%$ are shown (1000 resamplings) at nodes. Solid circles indicate that the corresponding nodes were also recovered in maximum-likelihood and maximum-parsimony trees. Bar, 0.02 nucleotide substitutions per site.

a different position in the polar lipid profile compared with that of a major unidentified lipid of C. marinus (i.e. L1; Supplementary Fig. S2). In addition, the absence of minor polar lipids (i.e. PC, PL2 and L2-4; Supplementary Fig. S2) differentiated strain CL-SK $30^{\mathrm{T}}$ from C. marinus. Strain CL$\mathrm{SK} 30^{\mathrm{T}}$ could also be distinguished from $C$. marinus by certain phenotypic traits: the ability to produce $\alpha$ chymotrypsin, cystine arylamidase, $\alpha$-glucosidase, trypsin and valine arylamidase, and the inability to produce acid phosphatase and lipase (C14) (Table 1). Strain CL-SK30 ${ }^{\mathrm{T}}$ could also be differentiated from the phylogenetically related genus Devosia in the family Hyphomicrobiaceae 
based on chemotaxonomic and phenotypic characteristics. The presence of the sole major respiratory quinone (Q-10) also differentiated strain CL-SK30 ${ }^{\mathrm{T}}$ from the genus Devosia (Table 1). In addition, the presence of certain polar lipids (i.e. GL1, GL2, PL1, L, PE and APL; Supplementary Fig. S2) clearly distinguished strain CL-SK30 ${ }^{\mathrm{T}}$ from Devosia geojensis (Ryu et al., 2008). Strain CL-SK30 ${ }^{\mathrm{T}}$ could also be differentiated from the genus Devosia by certain phenotypic traits: the ability to hydrolyse gelatin and to produce $\alpha$-chymotrypsin and cystine arylamidase (Table 1 ).

The phylogenetic, chemotaxonomic and physiological data obtained in this study indicate that strain CL-SK $30^{\mathrm{T}}$ should be assigned as representing a novel genus and species in the family Hyphomicrobiaceae, for which the name Maritalea myrionectae gen. nov., sp. nov. is proposed.

\section{Description of Maritalea gen. nov.}

Maritalea (Ma.ri.ta'le.a. L. neut. n. mare the sea; L. fem. n. talea a staff, rod; N.L. fem. n. Maritalea rod inhabiting marine environments).

Cells are Gram-negative and rod-shaped. Motile by means of peritrichous flagella. Growth is strictly aerobic. Oxidaseand catalase-positive. Major polar lipids are PG, DPG, two unidentified glycolipids, an unidentified phospholipid and an unidentified lipid. Major cellular fatty acids are $\mathrm{C}_{18: 1} \omega 7 c$ and 11-methyl $\mathrm{C}_{18: 1} \omega 7 c$. The isoprenoid quinone is Q-10. Phylogenetically, the genus is a member of the family Hyphomicrobiaceae. The type species is Maritalea myrionectae.

\section{Description of Maritalea myrionectae sp. nov.}

Maritalea myrionectae (my.ri' o.nec.tae. N.L. gen. n. myrionectae of Myrionecta rubra, the generic name of the ciliate from which the type strain was isolated).

Exhibits the following properties in addition to those given in the genus description. After 3 days on MA plates at $30{ }^{\circ} \mathrm{C}$, colonies are circular, convex, creamy and approximately $1 \mathrm{~mm}$ in diameter. Cells are approximately $0.4-0.5 \mu \mathrm{m}$ wide and $1.0-2.0 \mu \mathrm{m}$ long. Grows at $10-40{ }^{\circ} \mathrm{C}$ (optimum, 30 $35{ }^{\circ} \mathrm{C}$ ) and $\mathrm{pH}$ 6.3-9.8 (optimum, $\mathrm{pH} 7.2-8.0$ ). Growth occurs at sea salts concentrations of $1-10 \%(\mathrm{w} / \mathrm{v})$ (optimum, 2-5\%). PHB and bacteriochlorophyll $a$ are absent. Bud formation is observed. Gelatin, starch and Tween 80 are hydrolysed. According to the API ZYM system, alkaline phosphatase, $\alpha$-chymotrypsin, cystine arylamidase, esterase (C4), esterase lipase (C8), $\beta$-galactosidase, $\alpha$ - and $\beta$ glucosidases, leucine arylamidase, naphthol-AS-BI-phosphohydrolase, trypsin and valine arylamidase are positive, whereas $N$-acetyl- $\beta$-glucosaminidase, acid phosphatase, $\alpha$-fucosidase, $\alpha$-galactosidase, $\beta$-glucuronidase, lipase (C14) and $\alpha$-mannosidase are negative. Utilizes L-arabinose, L-arginine, L-asparagine, betaine, D-fructose, D-galactose, Dglucose, glutamic acid, glycerol, lactose, D-leucine, L-leucine, D-mannitol, mannose, pyuvate, sucrose and trehalose, but not DL-cysteine, dimethylsulfide, glycine, $p$-hydroxyphenylacetate, maleic acid, succinate or urea as a sole carbon. Cells are sensitive to ( $\mu \mathrm{g}$ per disc) cephalexin (30), chloramphenicol (30), erythromycin (15), gentamicin (10), kanamycin (30), nalidixic acid (30), penicillin $G(10)$ and vancomycin (30), but resistant to streptomycin (10). In addition to the polar lipids listed in the genus description, minor or trace amounts of phosphatidylethanolamine and an unidentified aminophospholipid can be detected. The $\mathrm{G}+\mathrm{C}$ content of DNA of the type strain is $52.7 \mathrm{~mol} \%$.

The type strain, CL-SK30 ${ }^{\mathrm{T}} \quad\left(=\mathrm{KCCM} 90060^{\mathrm{T}}=\mathrm{DSM}\right.$ $\left.19524^{\mathrm{T}}\right)$, was isolated from a culture of the marine ciliate Myrionecta rubra.

\section{Acknowledgements}

We acknowledge the expert technical support of Ms In-Sung Lee (electron microscopy) of the National Center for Inter-university Research Facilities at Seoul National University. This work was supported in part by the Ministry of Maritime Affairs and Fisheries (the Korea EAST-1 program) to B.C.C., the BK21 project of the Korean Government to B.C.C. \& C.Y.H. and a NRL grant from MOST \& KOSEF (M1-0302-00-0068) to W. Y.

\section{References}

Allgaier, M., Uphoff, H., Felske, A. \& Wagner-Döbler, I. (2003). Aerobic anoxygenic photosynthesis in Roseobacter clade bacteria from diverse marine habitats. Appl Environ Microbiol 69, 5051-5059.

Altschul, S. F., Gish, W., Miller, W., Myers, E. W. \& Lipman, D. J. (1990). Basic local alignment search tool. J Mol Biol 215, 403-410.

Bauer, A. W., Kirby, W. M. M., Sherris, J. C. \& Turck, M. (1966). Antibiotic susceptibility testing by a standardized single disk method. Am J Clin Pathol 45, 493-496.

Baumann, P. \& Baumann, L. (1981). The marine gram-negative eubacteria: genera Photobacterium, Beneckea, Alteromonas, Pseudomonas, and Alcaligenes. In The Prokaryotes, pp. 1302-1330. Edited by M. P. Starr, H. Stolp, H. G. Trüper, A. Balows \& H. G. Schlegel. Berlin: Springer.

Biebl, H., Allgaier, M., Tindall, B. J., Koblizek, M., Lünsdorf, H., Pukall, R. \& Wagner-Döbler, I. (2005). Dinoroseobacter shibae gen. nov., sp. nov., a new aerobic phototrophic bacterium isolated from dinoflagellates. Int J Syst Evol Microbiol 55, 1089-1096.

Cole, J. R., Chai, B., Farris, R. J., Wang, Q., Kulam-Syed-Mohideen, A. S., McGarrell, D. M., Bandela, A. M., Cardenas, E., Garrity, G. M. \& other authors (2007). The ribosomal database project (RDP-II): introducing $m y R D P$ space and quality controlled public data. Nucleic Acids Res 35, D169-D172.

Collins, M. D. (1985). Analysis of isoprenoid quinones. Methods Microbiol 18, 329-366.

Englen, M. D. \& Kelley, L. C. (2000). A rapid DNA isolation procedure for the identification of Campylobacter jejuni by the polymerase chain reaction. Lett Appl Microbiol 31, 421-426.

Felsenstein, J. (1981). Evolutionary trees from DNA sequences: a maximum likelihood approach. J Mol Evol 17, 368-376.

Fitch, W. M. (1971). Toward defining the course of evolution: minimum change for a specific tree topology. Syst Zool 20, 406-416.

Garrity, G. M., Bell, J. A. \& Lilburn, T. (2005). Family VIII. Hyphomicrobiaceae Babudieri 1950, 589. In Bergey's Manual of Systematic Bacteriology, 2nd edn, vol. 2, The Proteobacteria, part C, The Alpha-, 
Beta-, Delta-, and Epsilonproteobacteria, pp. 476-566. Edited by D. J. Brenner, N. R. Krieg, J. T. Staley \& G. M. Garrity. New York: Springer.

Goodfellow, M., Manfio, G. P. \& Chun, J. (1997). Towards a practical species concept for cultivable bacteria. In Species: the Units of Biodiversity, pp. 25-59. Edited by M. F. Claridge, H. A. Dawah \& M. R. Wilson. London: Chapman Hall.

Hansen, G. H. \& Sørheim, R. (1991). Improved method for phenotypical characterization of marine bacteria. J Microbiol Methods 13, 231-241.

Hwang, C. Y. \& Cho, B. C. (2008). Cucumibacter marinus gen. nov., sp. nov., a novel marine bacterium in the family Hyphomicrobiaceae. Int $J$ Syst Evol Microbiol 58, 1591-1597.

Jeon, Y.-S., Chung, H., Park, S., Hur, I., Lee, J.-H. \& Chun, J. (2005). jPHYDIT: a JAVA-based integrated environment for molecular phylogeny of ribosomal RNA sequences. Bioinformatics 21, 3171-3173.

Jukes, T. H. \& Cantor, C. R. (1969). Evolution of protein molecules. In Mammalian Protein Metabolism, pp. 21-132. Edited by H. N. Munro. New York: Academic Press.

Komagata, K. \& Suzuki, K. (1987). Lipid and cell-wall analysis in bacterial systematics. Methods Microbiol 19, 161-207.

Lane, D. J. (1991). 16S/23S rRNA sequencing. In Nucleic Acid Techniques in Bacterial Systematics, pp. 115-175. Edited by E. Stackebrandt \& M. Goodfellow. Chichester: Wiley.

Lee, S. D. (2007). Devosia subaequoris sp. nov., isolated from beach sediment. Int J Syst Evol Microbiol 57, 2212-2215.

Lemos, M. L., Toranzo, A. E. \& Barja, J. L. (1985). Modified medium for the oxidation-fermentation test in the identification of marine bacteria. Appl Environ Microbiol 49, 1541-1543.

Lyman, J. \& Fleming, R. H. (1940). Composition of sea water. J Mar Res 3, 134-146.

Marmur, J. (1961). A procedure for the isolation of deoxyribonucleic acid from microorganisms. J Mol Biol 3, 208-218.

Martens, T., Heidorn, T., Pukall, R., Simon, M., Tindall, B. J. \& Brinkhoff, T. (2006). Reclassification of Roseobacter gallaeciensis RuizPonte et al. 1998 as Phaeobacter gallaeciensis gen. nov., comb. nov., description of Phaeobacter inhibens sp. nov., reclassification of Ruegeria algicola (Lafay et al. 1995) Uchino et al. 1999 as Marinovum algicola gen. nov., comb. nov., and emended descriptions of the genera Roseobacter, Ruegeria and Leisingera. Int J Syst Evol Microbiol 56, 1293-1304.

Mesbah, M., Premachandran, U. \& Whitman, W. B. (1989). Precise measurement of the $\mathrm{G}+\mathrm{C}$ content of deoxyribonucleic acid by highperformance liquid chromatography. Int J Syst Bacteriol 39, 159-167.

Minnikin, D. E., O’Donnell, A. G., Goodfellow, M., Alderson, G., Athalye, M., Schaal, A. \& Parlett, J. H. (1984). An integrated procedure for the extraction of bacterial isoprenoid quinones and polar lipids. J Microbiol Methods 2, 233-241.

Nakagawa, Y., Sakane, T. \& Yokota, A. (1996). Transfer of "Pseudomonas riboflavina" (Foster 1944), a Gram-negative, motile rod with long-chain 3-hydroxy fatty acids, to Devosia riboflavina gen. nov., sp. nov., nom. rev. Int J Syst Bacteriol 46, 16-22.

Ostle, A. G. \& Holt, J. G. (1982). Nile blue A as fluorescent stain for poly- $\beta$-hydroxybutyrate. Appl Environ Microbiol 44, 238-241.

Posada, D. \& Crandall, K. A. (1998). MODELTEST: testing the model of DNA substitution. Bioinformatics 14, 817-818.

Rivas, R., Willems, A., Subba-Rao, N. S., Mateos, P. F., Dazzo, F. B., Kroppenstedt, R. M., Martínez-Molina, E., Gillis, M. \& Velázquez, E. (2003). Description of Devosia neptuniae sp. nov. that nodulates and fixes nitrogen in symbiosis with Neptunia natans, an aquatic legume from India. Syst Appl Microbiol 26, 47-53.

Ryu, S. H., Chung, B. S., Le, N. T., Jang, H. H., Yun, P.-Y., Park, W. \& Jeon, C. O. (2008). Devosia geojensis sp. nov., isolated from dieselcontaminated soil in Korea. Int J Syst Evol Microbiol 58, 633-636.

Saitou, N. \& Nei, M. (1987). The neighbor-joining method: a new method for reconstructing phylogenetic trees. Mol Biol Evol 4, 406-425.

Smibert, R. M. \& Krieg, N. R. (1994). Phenotypic characterization. In Methods for General and Molecular Bacteriology, pp. 607-654. Edited by P. Gerhardt, R. G. E. Murray, W. A. Wood \& N. R. Krieg. Washington, DC: American Society for Microbiology.

Stackebrandt, E. \& Liesack, W. (1993). Nucleic acids and classification. In Handbook of New Bacterial Systematics, pp. 151-194. Edited by M. Goodfellow \& A. G. O’Donnell. London: Academic Press.

Suzuki, M., Nakagawa, Y., Harayama, S. \& Yamamoto, S. (2001). Phylogenetic analysis and taxonomic study of marine Cytophaga-like bacteria: proposal for Tenacibaculum gen. nov. with Tenacibaculum maritimum comb. nov. and Tenacibaculum ovolyticum comb. nov., and description of Tenacibaculum mesophilum sp. nov. and Tenacibaculum amylolyticum sp. nov. Int J Syst Evol Microbiol 51, $1639-1652$.

Swofford, D. L. (1998). PAUP*: Phylogenetic analysis using parsimony (and other methods), version 4. Sunderland, MA: Sinauer Associates.

Tamura, K., Dudley, J., Nei, M. \& Kumar, S. (2007). MEGA4: molecular evolutionary genetics analysis (MEGA) software version 4.0. Mol Biol Evol 24, 1596-1599.

Yih, W., Kim, H. S., Jeong, H. J., Myung, G. \& Kim, Y. G. (2004). Ingestion of cryptophyte cells by the marine photosynthetic ciliate Mesodinium rubrum. Aquat Microb Ecol 36, 165-170.

Yoo, S.-H., Weon, H.-Y., Kim, B.-Y., Hong, S.-B., Kwon, S.-W., Cho, Y.-H., Go, S.-J. \& Stackebrandt, E. (2006). Devosia soli sp. nov., isolated from greenhouse soil in Korea. Int J Syst Evol Microbiol 56, 2689-2692.

Yoon, J.-H., Lee, M.-H. \& Oh, T.-K. (2004). Porphyrobacter donghaensis sp. nov., isolated from sea water of the East Sea in Korea. Int J Syst Evol Microbiol 54, 2231-2235.

Yoon, J.-H., Kang, S.-J., Park, S. \& Oh, T.-K. (2007). Devosia insulae sp. nov., isolated from soil, and emended description of the genus Devosia. Int J Syst Evol Microbiol 57, 1310-1314. 